\title{
\#USES
}

Prepared in cooperation with the

City of Ithaca, New York, and the New York State Department of State

Bathymetric Survey of the Cayuga Inlet Flood-Control Channel and Selected Tributaries in Ithaca, New York, 2016

Open-File Report 2017-1109

U.S. Department of the Interior

U.S. Geological Survey 
Cover. "Upstream view of Cayuga Inlet, Ithaca, New York" (Photograph by William F. Coon, U.S. Geological Survey) 


\section{Bathymetric Survey of the Cayuga Inlet Flood-Control Channel and Selected Tributaries in Ithaca, New York, 2016}

By John F. Wernly, Elizabeth A. Nystrom, and William F. Coon

Prepared in cooperation with the

City of Ithaca, New York, and the New York State Department of State

Open-File Report 2017-1109 


\title{
U.S. Department of the Interior \\ RYAN K. ZINKE, Secretary
}

\section{U.S. Geological Survey William H. Werkheiser, Acting Director}

\author{
U.S. Geological Survey, Reston, Virginia: 2017
}

For more information on the USGS - the Federal source for science about the Earth, its natural and living resources, natural hazards, and the environment-visit https://www.usgs.gov or call 1-888-ASK-USGS.

For an overview of USGS information products, including maps, imagery, and publications, visit https://store.usgs.gov.

Any use of trade, firm, or product names is for descriptive purposes only and does not imply endorsement by the U.S. Government.

Although this information product, for the most part, is in the public domain, it also may contain copyrighted materials as noted in the text. Permission to reproduce copyrighted items must be secured from the copyright owner.

Suggested citation:

Wernly, J.F., Nystrom, E.A., and Coon, W.F., 2017, Bathymetric survey of the Cayuga Inlet flood-control channel and selected tributaries in Ithaca, New York, 2016: U.S. Geological Survey Open-File Report 2017-1109, 9 p., https://doi.org/10.3133/ofr20171109.

ISSN 2331-1258 (online) 


\section{Contents}

Abstract
Introduction nathymetric Survey
Survey Plan
Horizontal and Vertical Control
Postprocessing of Bathymetric Data
Creation of Bathymetric Surface
Summary.
Acknowledgments
References Cited

\section{Figures}

1. Map showing locations of channels included in the bathymetric survey of the Cayuga Inlet flood-control channel and selected tributaries, Ithaca, New York. .............2

2. Map showing locations of transects for echo-sounder depth measurements from the bathymetric survey of the Cayuga Inlet flood-control channel and selected tributaries, Ithaca, New York

3. Map showing bathymetric surface of the Cayuga Inlet flood-control channel and selected tributaries, Ithaca, New York. 


\section{Conversion Factors}

U.S. customary units to International System of Units

\begin{tabular}{lcl}
\hline \multicolumn{1}{c}{ Multiply } & By & \multicolumn{1}{c}{ To obtain } \\
\hline & Length & \\
\hline inch (in.) & 2.54 & centimeter $(\mathrm{cm})$ \\
inch (in.) & 25.4 & millimeter $(\mathrm{mm})$ \\
foot (ft) & 0.3048 & meter $(\mathrm{m})$ \\
mile (mi) & 1.609 & kilometer $(\mathrm{km})$ \\
\hline & Area & \\
\hline square mile $\left(\mathrm{mi}^{2}\right)$ & 2.590 & square kilometer $\left(\mathrm{km}^{2}\right)$ \\
\hline & Volume & \\
\hline quart (qt) & 0.9464 & liter $(\mathrm{L})$ \\
\hline & Velocity & meter per second $(\mathrm{m} / \mathrm{s})$ \\
\hline foot per second $(\mathrm{ft} / \mathrm{s})$ & 0.3048 & gram $(\mathrm{g})$ \\
\hline
\end{tabular}

Temperature in degrees Fahrenheit $\left({ }^{\circ} \mathrm{F}\right)$ may be converted to degrees Celsius $\left({ }^{\circ} \mathrm{C}\right)$ as follows:

$$
{ }^{\circ} \mathrm{C}=\left({ }^{\circ} \mathrm{F}-32\right) / 1.8
$$

\section{Datum}

Vertical coordinate information is referenced to either the National Geodetic Vertical Datum of 1929 (NGVD 29) or the North American Vertical Datum of 1988 (NAVD 88).

Horizontal coordinate information is referenced to the North American Datum of 1983 (NAD 83).

Elevation, as used in this report, refers to distance above the vertical datum.

\section{Supplemental Information}

Concentrations of chemical constituents in water are given in parts per thousand, which is equivalent to grams per liter. 


\section{Abbreviations}

$\begin{array}{ll}\text { ADCP } & \text { acoustic Doppler current profiler } \\ \text { GIS } & \text { geographic information system } \\ \text { GPS } & \text { Global Positioning System } \\ \text { RMSE } & \text { root mean square error } \\ \text { RTK } & \text { real-time kinematic } \\ \text { TIN } & \text { triangular irregular network } \\ \text { USACE } & \text { U.S. Army Corps of Engineers } \\ \text { USGS } & \text { U.S. Geological Survey }\end{array}$





\title{
Bathymetric Survey of the Cayuga Inlet Flood-Control Channel and Selected Tributaries in Ithaca, New York, 2016
}

\author{
By John F. Wernly, Elizabeth A. Nystrom, and William F. Coon
}

\begin{abstract}
From July 14 to July 20, 2016, the U.S. Geological Survey, in cooperation with the City of Ithaca, New York, and the New York State Department of State, surveyed the bathymetry of the Cayuga Inlet flood-control channel and the mouths of selected tributaries to Cayuga Inlet and Cayuga Lake in Ithaca, N.Y. The flood-control channel, built by the U.S. Army Corps of Engineers between 1965 and 1970, was designed to convey flood flows from the Cayuga Inlet watershed through the City of Ithaca and minimize possible flood damages. Since that time, the channel has infrequently been maintained by dredging, and sediment accumulation and resultant shoaling have greatly decreased the conveyance of the channel and its navigational capability.

U.S. Geological Survey personnel collected bathymetric data by using an acoustic Doppler current profiler. The survey produced a dense dataset of water depths that were converted to bottom elevations. These elevations were then used to generate a geographic information system bathymetric surface. The bathymetric data and resultant bathymetric surface show the current condition of the channel and provide the information that governmental agencies charged with maintaining the Cayuga Inlet for flood-control and navigational purposes need to make informed decisions regarding future maintenance measures.
\end{abstract}

\section{Introduction}

The Cayuga Inlet basin covers 158 square miles $\left(\mathrm{mi}^{2}\right)$ that drain to the southern end of Cayuga Lake, where the City of Ithaca, Tompkins County, New York, is located. The inlet, which flows northward, has two tributaries, Sixmile and Cascadilla Creeks, that flow westward through Ithaca to join
Cayuga Inlet 1.4 and 0.6 miles (mi), respectively, upstream from its mouth. A third stream, Fall Creek, also flows through Ithaca but discharges directly into Cayuga Lake (fig. 1). Although infrequent, these four streams, either individually or collectively, have the potential to cause great damage to city properties and infrastructure when they flood. The magnitude and extent of flooding can be affected by the water level of Cayuga Lake; high lake levels prevent drainage of flooded areas through storm-sewer pipes, which under extremely high water levels can be the source of flooding as water backs up through these conduits. Flood extents can also be affected by any decrease in the conveyance of storm flows through Cayuga Inlet.

The 2.3-mi-long Cayuga Inlet flood-control channel was built by the U.S. Army Corps of Engineers (USACE) between 1965 and 1970 to convey flood flows through the City of Ithaca and minimize flood damages similar to those that occurred during the inlet's period-of-record flood on July 8, 1935 (U.S. Army Corps of Engineers, 2011; New York State Department of Environmental Conservation, 2016). However, with time, this design goal has been thwarted by (1) sedimentation and shoaling in the low-gradient, over-widened, and over-deepened channel that is also under the backwater influence of Cayuga Lake, and (2) the lack of maintenance dredging during the channel's 46-year existence (U.S. Army Corps of Engineers, 2011). Dredging of the inlet has become a critical need for the City of Ithaca, and a realistic estimate of the volume of sediment that might need to be removed is required. The first step toward that estimate is an accurate map of the channel bottom that could then be compared with asbuilt flood-control channel (circa 1970) cross-sectional data. Mapping also is integral to flood-inundation modeling of the Cayuga Inlet channels.

The U.S. Geological Survey (USGS) provides reliable scientific information to describe hydrologic systems and assists in understanding how hydrologic and geomorphic 


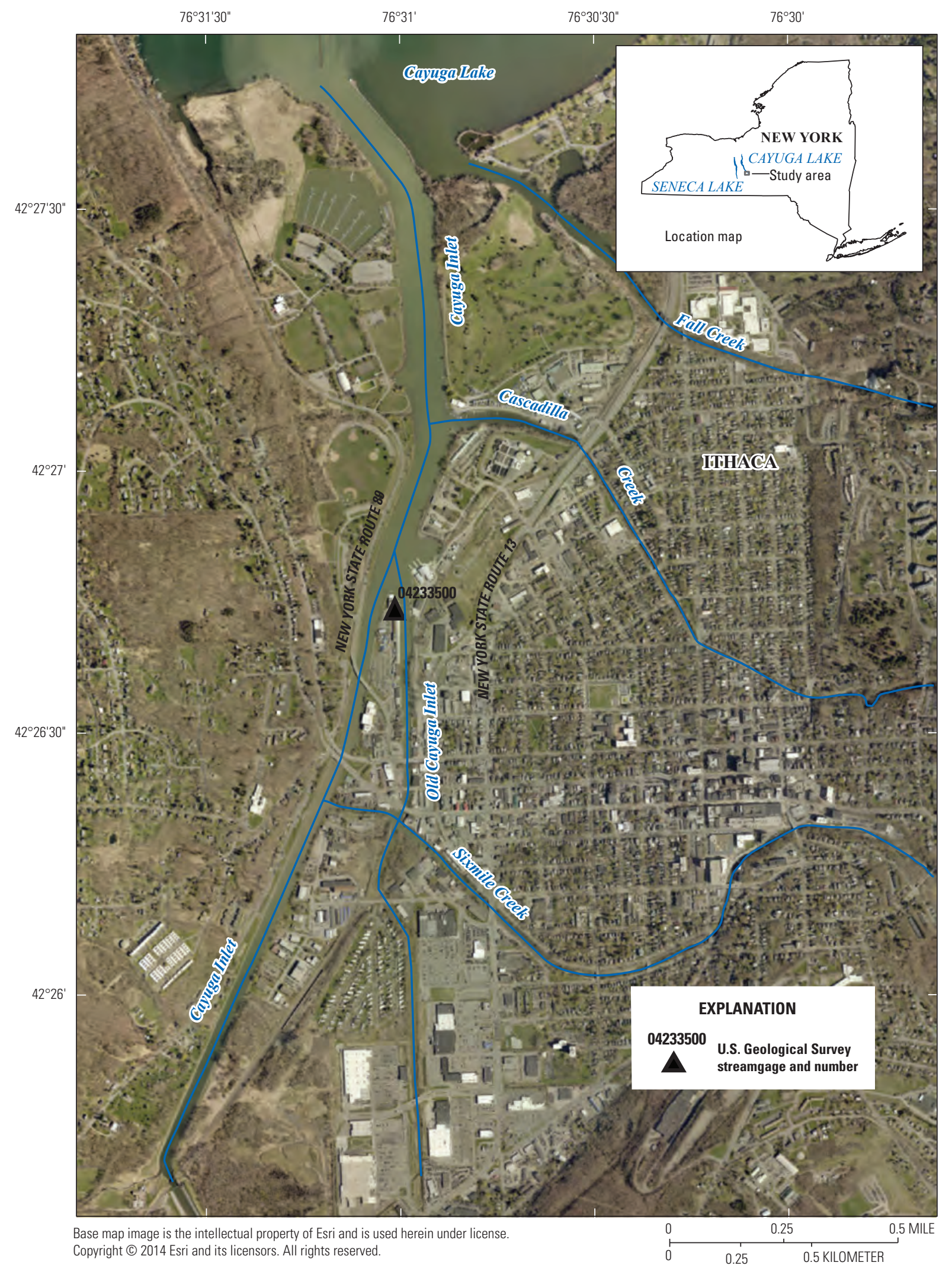

Figure 1. Locations of channels included in the bathymetric survey of the Cayuga Inlet flood-control channel and selected tributaries, Ithaca, New York. The blue lines on the base image are enhancements to highlight the stream channels. 
conditions can change with time. In most instances, the USGS documents and analyzes the effects of widely recognized phenomena, such as surface-water and groundwater flow and quality. On occasion, this information involves small-scope studies of recognized phenomenon, such as shoaling of the Cayuga Inlet flood-control channel, which had not been previously documented at a scale to adequately meet the needs of governmental agencies, including the USACE, the New York State Department of Environmental Conservation, and the City of Ithaca. The USGS works within its strategic science direction and with its cooperative partners, such as the City of Ithaca, to document emerging environmental conditions and (or) hazards and to ensure that scientific methods are applied effectively to better understand these phenomena and thereby inform environmental managers on water resources and associated infrastructure.

The USGS, in cooperation with the City of Ithaca, N.Y., and the New York State Department of State, as a project of the Title 11 of the Environmental Protection Fund, surveyed the bathymetry of the Cayuga Inlet flood-control channel, including the Old Cayuga Inlet channel; the downstream ends of two tributaries to Cayuga Inlet, Sixmile and Cascadilla Creeks; and the downstream end of one tributary to Cayuga Lake, Fall Creek. The survey extents of each of these tributary reaches was from their respective mouths upstream to New York State Route 13 in Ithaca (fig. 1). The survey was conducted to meet the modeling needs of a concurrent floodinundation mapping study that was being conducted by the USGS. The bathymetric data also provided a picture of the current (2016) condition of the flood-control channel, which can inform government agencies charged with maintaining the depth of the flood-control channel to design specifications and the navigational capacity of the inlet as part of the New York State Canal System.

The purpose of this report is to document the procedures followed during collection of bathymetric data from the flood-control channel of Cayuga Inlet, as well as the mouths of Sixmile Creek, Cascadilla Creek, and Fall Creek. The report describes the collection of depth data by an acoustic Doppler current profiler (ADCP), the processing of the depth data, and the assessment of the accuracy of the depth measurements. A map of the bathymetric surface of the inlet and the three tributaries is presented. These data are available as a separate data release through USGS ScienceBase (Wernly and Nystrom, 2016).

\section{Bathymetric Survey}

The main component of the bathymetric survey is the 2.3-mi-long Cayuga Inlet flood-control channel from the railroad bridge and weir at the upstream end of the channel to its mouth at Cayuga Lake (fig. 1). Secondary components of the survey are the Old Cayuga Inlet channel from its intersection with Sixmile Creek to its confluence with the flood-control channel and the downstream ends of Sixmile, Cascadilla, and Fall Creeks from their respective mouths upstream to New York State Route 13.

Bathymetric data were collected with an ADCP, specifically a SonTek RiverSurveyor M9 with a 0.5-megahertz $(\mathrm{MHz})$ integral vertical-beam echo sounder (SonTek, 2015a). In the shallowest areas of the surveyed reach, data were collected using the RiverSurveyor M9's dual four-beam velocity measurement transducers with four beams at $3.0 \mathrm{MHz}$ and four beams at $1.0 \mathrm{MHz}$, and with both in Janus configuration and set at a 25-degree slant angle. An echo sounder measures water depths by measuring the time interval required for ultrasonic waves to travel, at a known velocity, from a known point (transducer face) to a reflecting surface (channel bottom) and then return. The dual four-beam transducers measure water depth by the same means, taking into account their slant angle. When either the $1.0-\mathrm{MHz}$ or $3.0-\mathrm{MHz}$ transducers are operating (only one frequency is operational at a time), four depths are measured (one per beam). The reported depth value is the average of the four measured depths.

A minimum depth limitation applies when the reflecting surface is too close to the echo-sounder face. The minimum depth limitation using the vertical-beam echo sounder was generally less than about 1.9 feet (ft) during the survey. With the dual four-beam transducers, however, it was possible to decrease the minimum depth limitation to $1.4 \mathrm{ft}$. This decrease in the minimum measureable depth permitted the extension of the survey to shallow areas, particularly the most upstream portions of the tributaries where water depths decreased as the elevations of the streambeds increased. Survey points were georeferenced using a real-time kinematic (RTK) Global Positioning System (GPS) that is a component of the ADCP.

The velocity of sound in water is dependent on the salinity, temperature, and depth. The salinity and shallow depths in freshwater bodies are not major factors that affect the sound velocity (U.S. Army Corps of Engineers, 2002). Regardless, salinity was measured daily at the surface and at a depth of $5 \mathrm{ft}$; additional measurements were made at $10 \mathrm{ft}$ when the depth permitted. Salinities at the surface and at both depths were determined to be identical on a given survey day and ranged from 0.2 to 0.3 parts per thousand among the survey days. An ADCP has built-in temperature sensors that measure water temperature at the transducer face and permits the computation of the sound velocity and the subsequent accurate measurement of depth. To confirm the accuracy of the ADCP's sound-velocity calculation, surface-water temperature was measured independently by means of a thermistor. Throughout the survey the ADCP temperature sensor varied by no more than 0.7 degrees Fahrenheit $\left({ }^{\circ} \mathrm{F}\right)\left(0.4\right.$ degrees Celsius, $\left.{ }^{\circ} \mathrm{C}\right)$ from the independently measured surface-water temperatures, with a mean absolute difference of $0.4{ }^{\circ} \mathrm{F}\left(0.2^{\circ} \mathrm{C}\right)$. The water temperatures recorded at depths of 5 and $10 \mathrm{ft}$ varied by no more than $3.1^{\circ} \mathrm{F}\left(1.7^{\circ} \mathrm{C}\right)$ from the measured surface temperature, with a mean absolute difference of $1.3{ }^{\circ} \mathrm{F}\left(0.7^{\circ} \mathrm{C}\right)$. Therefore, no variation in sound velocity with depth, as a 
function of change in temperature, was expected in this shallow environment.

Before surveying each day, the depth readings of the vertical-beam echo sounder were checked by means of a bar check to ensure accurate depth sounding. A horizontal plate was suspended at known depths -5 and $10 \mathrm{ft}$-directly below the transducer face. The depth indicated by the vertical-beam echo sounder signal that was reflected off the submerged plate was compared with the known depth of the plate. The bar check was not used to ensure accurate depth soundings for the dual four-beam transducers.

All data were referenced to the horizontal datum, North American Datum of 1983 (NAD 83), and vertical datum, North American Vertical Datum of 1988 (NAVD 88). The survey was conducted from July 14 to July 20, 2016.

\section{Survey Plan}

Guidelines for conducting a bathymetric survey as described by Wilson and Richards (2006) were followed. The planned survey transects were arranged perpendicular to the centerline of each channel. HYPACK software (HYPACK, Inc., 2015) was used to map the transects, along which water depths were measured, over the length of the inlet and thus enabled the collection of consistently spaced water depths. Transects composed of series of survey points were spaced about $100 \mathrm{ft}$ apart (fig. 2). A georeferenced aerial image of the channel was used within HYPACK for office planning of transects and for guidance of the survey team in the field. The survey team used an onboard differential GPS (separate from the RTK GPS that is a component of the ADCP) that was coupled to a computer, on which HYPACK was running, to navigate the transects in real time and keep track of their datacollection progress.

For quality assurance, a second survey was conducted to provide an independent dataset with which the vertical accuracies of the ADCP data could be assessed (fig. 2). This quality-assurance survey, which was conducted during the same time period as the principal survey, was run down the center of the channel. At every intersection between the first and second surveys, a coincident point was later extracted for depth-accuracy analysis.

\section{Horizontal and Vertical Control}

Horizontal survey positions for the ADCP were acquired through the use of an RTK GPS receiver positioned directly above the ADCP where depths were measured. This unit received horizontal-location corrections from an onshore RTK base station, which was periodically repositioned to maintain line of sight and thus maintain reliable communication with the survey vessel and provided a manufacturer-stated horizontal survey accuracy of 3 centimeters $(\mathrm{cm})$ or $0.10 \mathrm{ft}$ relative to the base station. The software associated with the RiverSurveyor M9 ADCP, RiverSurveyor LIVE (version 3.8; SonTek, 2015b), does not allow input of a control-point location for the base station, nor does it allow for the logging of observations that could be postprocessed by the National Geodetic Survey Online Positioning User Service (National Geodetic Survey, 2015). RiverSurveyor LIVE is designed for measuring streamflow where the absolute georeferenced location of the ADCP is not critical to a precision of plus or minus $3 \mathrm{~cm}$. The system uses the base station to correct the ADCP position to plus or minus $3 \mathrm{~cm}$ relative to itself for the purpose of accurately measuring stream width to calculate discharge. This system was adapted for bathymetric mapping by obtaining a high level of accuracy for the ADCP relative to the position of the RTK base station, whereas, without the ability to enter a controlpoint location for the RTK base station, the absolute position of the ADCP may only have attained submeter accuracy.

Latency is the time difference or lag between the time when positioning data are received and the time when the computed or processed position reaches the data logging module and is time tagged. Latency typically results in a negative along-track spatial displacement of depth measurements. This displacement can be minimized by surveying at slow speeds and by synchronizing the echo-sounder and GPS clocks. Boat speed was kept to a minimum and averaged 0.78 feet per second throughout the survey. The RiverSurveyor M9 ADCP minimizes latency through the use of the integrated RTK GPS located above the ADCP, which directly connects the incoming GPS data stream to the ADCP. Unlike other echo-sounder systems, the RiverSurveyor M9 ADCP performs internal calculations with the GPS data, synchronized by the system with a 10-hertz update rate, before the data are stored in the computer. Latency was not quantified, but it was considered small enough, given the slow survey speed and integrated GPS, that any potential errors in the data were negligible for this survey.

A vertical control point for the survey was provided by the USGS streamgage, Cayuga Inlet (Cayuga Lake) at Ithaca (station number 04233500; U.S. Geological Survey, 2016). The streamgage, located approximately midway along the study reach (fig. 1), continuously records the water-surface elevations of the inlet. The daily surveys were conducted on relatively calm days; water levels during a given survey period fluctuated by $0.10 \mathrm{ft}$ or less. The average of the water-surface elevations that were recorded during a given survey period was assumed to be constant throughout the survey reach. The mean water-surface elevations varied by only $0.15 \mathrm{ft}$ during the 4 days that the survey was conducted. Water-surface elevations recorded by the streamgage are referenced to National Geodetic Vertical Datum of 1929 and were converted to elevations above North American Vertical Datum of 1988 by using the datum conversion program, VERTCON (National Geodetic Survey, 2016). During postprocessing of the data, water depths (adjusted for the transducer depth) were subtracted from these water-surface elevations to obtain channel-bottom elevations. 


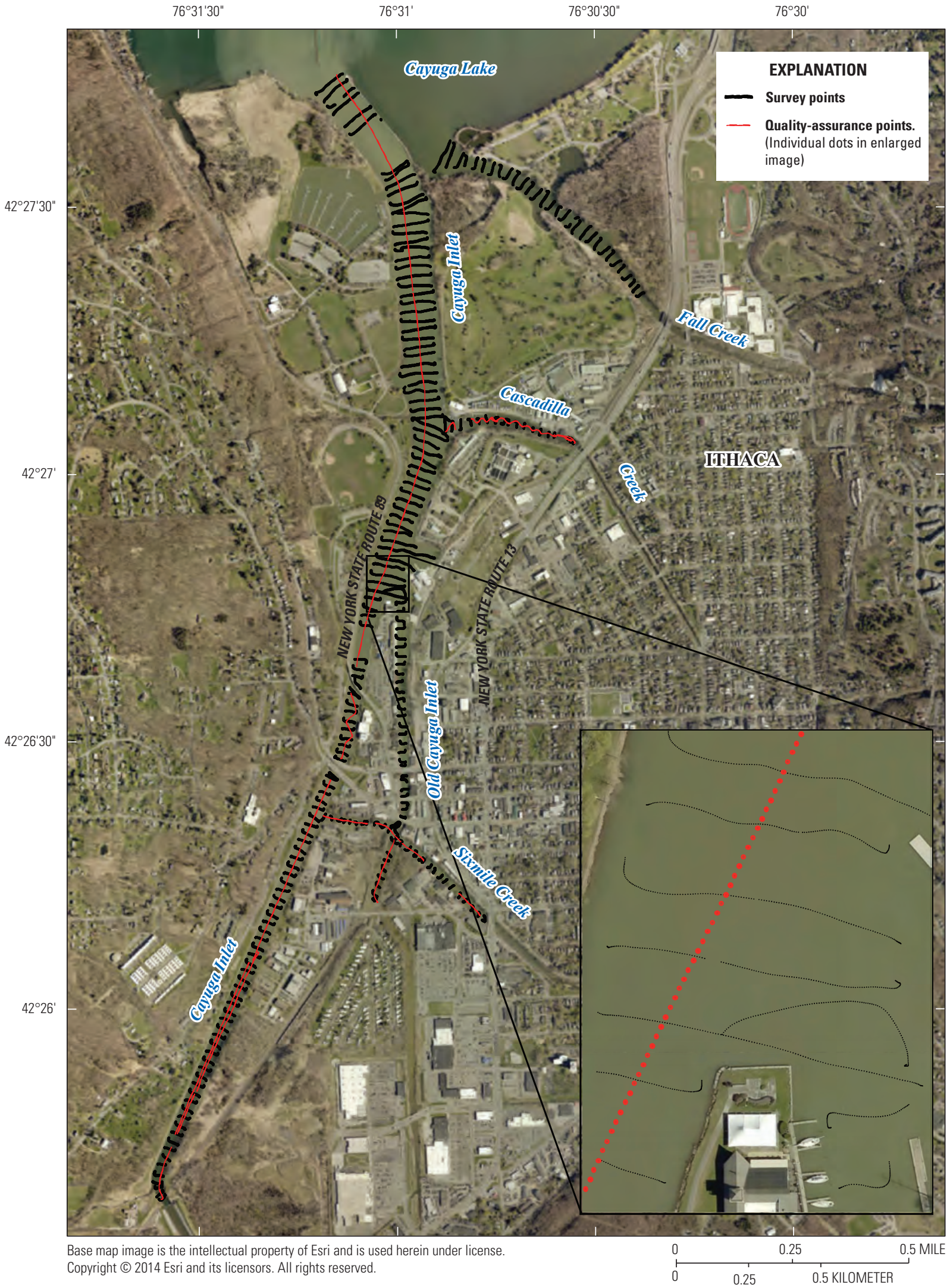

Figure 2. Locations of transects for echo-sounder depth measurements from the bathymetric survey of the Cayuga Inlet flood-control channel and selected tributaries, Ithaca, New York. 


\section{Postprocessing of Bathymetric Data}

Raw transect data were reviewed in RiverSurveyor LIVE, the software associated with the RiverSurveyor M9 ADCP (SonTek, 2015b), for erroneous measurements that could result from false reflections from fish, aquatic vegetation, or other submerged objects. In addition, those data that did not meet RTK quality, as sometimes occurred when the GPS signal was lost near bridges or line of site with the base station was impeded, were also identified. Of a total of 26,976 data points, 1,414 erroneous data points, or about 5.2 percent of the total survey, were removed. Most of these erroneous points were removed because they did not meet RTK quality, but a small number were removed due to interference from aquatic vegetation in the water column. The remaining transect data, consisting of 25,562 data points, were saved as edited transects.

The resultant data, after water depths were converted to channel-bottom elevations, were processed by using ArcGIS (version 10.3.1), which contains hydrographic software for data viewing and editing, data processing, generation of interpolated data, and creation of map products (Esri, 2016). These data are available as a data release (Wernly and Nystrom, 2016).

\section{Horizontal and Vertical Control Accuracy}

The horizontal positional accuracy of the RTK GPS receiver in the ADCP is $3 \mathrm{~cm}(0.10 \mathrm{ft})$ according to the manufacturer (SonTek, 2015a); however, horizontal accuracy is affected by the multipath environment (proximity to trees, buildings, cliffs, and so on), the number of satellites in view, satellite geometry, and ionospheric activity (SonTek, 2015a). No independent testing was conducted to confirm the stated horizontal accuracy of the survey, but for the purposes of this study, the exact location of a given surveyed point in space was deemed to be less important than the relative locations among the surveyed points and the distances between adjacent points; therefore, the manufacturer's level of accuracy was accepted as stated.

The vertical-beam echo sounder and the dual four-beam transducers used in this study have a resolution of 1 millimeter $(0.003 \mathrm{ft})$ and an accuracy of 1 percent of the measured depth, according to the manufacturer's specifications (SonTek, 2015a). A decrease in the accuracy of the average depth measured by the four-beam transducers can occur simply because the transducer beams are at a 25 -degree slant angle. In all but perfectly flat environments, each of the four beams will measure and record slightly different depths with the average of the four depths being the only reported value. As the depth of water increases, the areal footprint being measured by the four beams increases, which can potentially lead to greater differences in measured depths among the four individual beams. For this reason the four-beam depths were generally used only where depths were shallower than the vertical-beam echo sounder's minimum depth limitation of $1.90 \mathrm{ft}$. In these situations the areal footprint of the four-beam transducers was smallest and the potential error in depths was least. Four-beam transducer depths consisted of only 335 survey points or about 1.3 percent of the total of 25,562 points measured.

Central to this project was the belief that sedimentation near the mouths of the tributaries was as important as the current level of shoaling of Cayuga Inlet. Four-beam depth measurements provided data in the shallowest parts of the survey areas that otherwise would not have been mapped. These data more accurately defined shoaling in the Old Cayuga Inlet channel and the mouth of Cascadilla Creek and also enabled the survey to continue an additional $300 \mathrm{ft}$ upstream on Fall Creek, which would not have been possible with the verticalbeam echo sounder. Four-beam depth measurements also were made along the shallow edges of Cayuga Inlet.

An assessment of the vertical accuracy of the measured depths and resultant channel-bed elevations was possible by comparing results for coincident points measured in the primary set of transects (100-ft spacing though the entire study reach) and the quality-assurance survey (following a path along the center of the channel). One-hundred and fifty-five (155) paired intersection points were used for comparison. The horizontal distances between the paired points averaged $1.09 \mathrm{ft}$ and ranged from 0.18 to $1.60 \mathrm{ft}$. The absolute differences in elevations ranged from 0.00 to $0.88 \mathrm{ft}$; however, all except 14 paired points had differences within $0.20 \mathrm{ft}$ and the median absolute difference was $0.07 \mathrm{ft}$. The vertical root mean square error (RMSE) and the vertical accuracy of the elevations at the 95-percent confidence level were computed by using the following equations:

$$
R M S E_{z}=\sqrt{\frac{\sum_{i=1}^{n}\left(\text { Zorig }_{i}-Z_{\text {Za }}\right)^{2}}{n}},
$$

where

$R M S E_{z}$ is the vertical root mean square error, Zorig $_{i}$ is the vertical coordinate of the $i$ th check point in the original dataset, $Z q a_{i}$ is the vertical coordinate of the $i$ th check point in the quality-assurance dataset, $i$ is an integer from 1 to $n$, and $n$ is the number of points being checked.

$$
A_{z}=1.960 \times R M S E_{\mathrm{z}},
$$

where

$$
\begin{aligned}
& A_{\mathrm{z}} \text { is the vertical accuracy calculated at the } \\
& \text { 95-percent confidence level. }
\end{aligned}
$$

The RMSE of the ADCP-collected elevation data was $0.14 \mathrm{ft}$, and the vertical accuracy was $0.27 \mathrm{ft}$ at the 95 -percent confidence level. 


\section{Creation of Bathymetric Surface}

The Cayuga Inlet is about $150 \mathrm{ft}$ wide in the upstream half of the study reach (that is, upstream from New York State Route 89). This width gradually increases through the downstream half of the reach to more than $400 \mathrm{ft}$ near its mouth at Cayuga Lake. Midchannel depths typically ranged from $3.2 \mathrm{ft}$ to $13.5 \mathrm{ft}$ in the upstream part of the study reach, and $5.7 \mathrm{ft}$ to $10.3 \mathrm{ft}$ in the downstream part of the study reach. The greatest depth, $14.5 \mathrm{ft}$, was measured near the right bank of Cayuga Inlet near its confluence with Sixmile Creek.

The bathymetric data were used to produce a triangular irregular network (TIN) of the bottom of the Cayuga Inlet flood-control channel, including the Old Cayuga Inlet channel and the mouths of Sixmile Creek, Cascadilla Creek, and
Fall Creek (fig. 3). The TIN was created by connecting each point with its two nearest neighbors; for point data collected along transects, this creates a three-dimensional array of thin triangles. Breaklines that enforce connections between surveyed points were added to the computer-generated TIN to ensure accurate representation of the linear features of the channel bottoms ("linear enforcement," see Wilson and Richards, 2006). The TIN, which was created using ArcGIS software (Esri, 2016), was projected in a State plane (New York Central) coordinate system. From this TIN, a 2-ft cellsize raster was created using linear interpolation. This raster and the bathymetric data are available online (Wernly and Nystrom, 2016). These data and the generated bathymetric surface are not intended for navigation, regulatory, permitting, or other legal purposes. The USGS assumes no legal liability or responsibility resulting from the use of this information. 


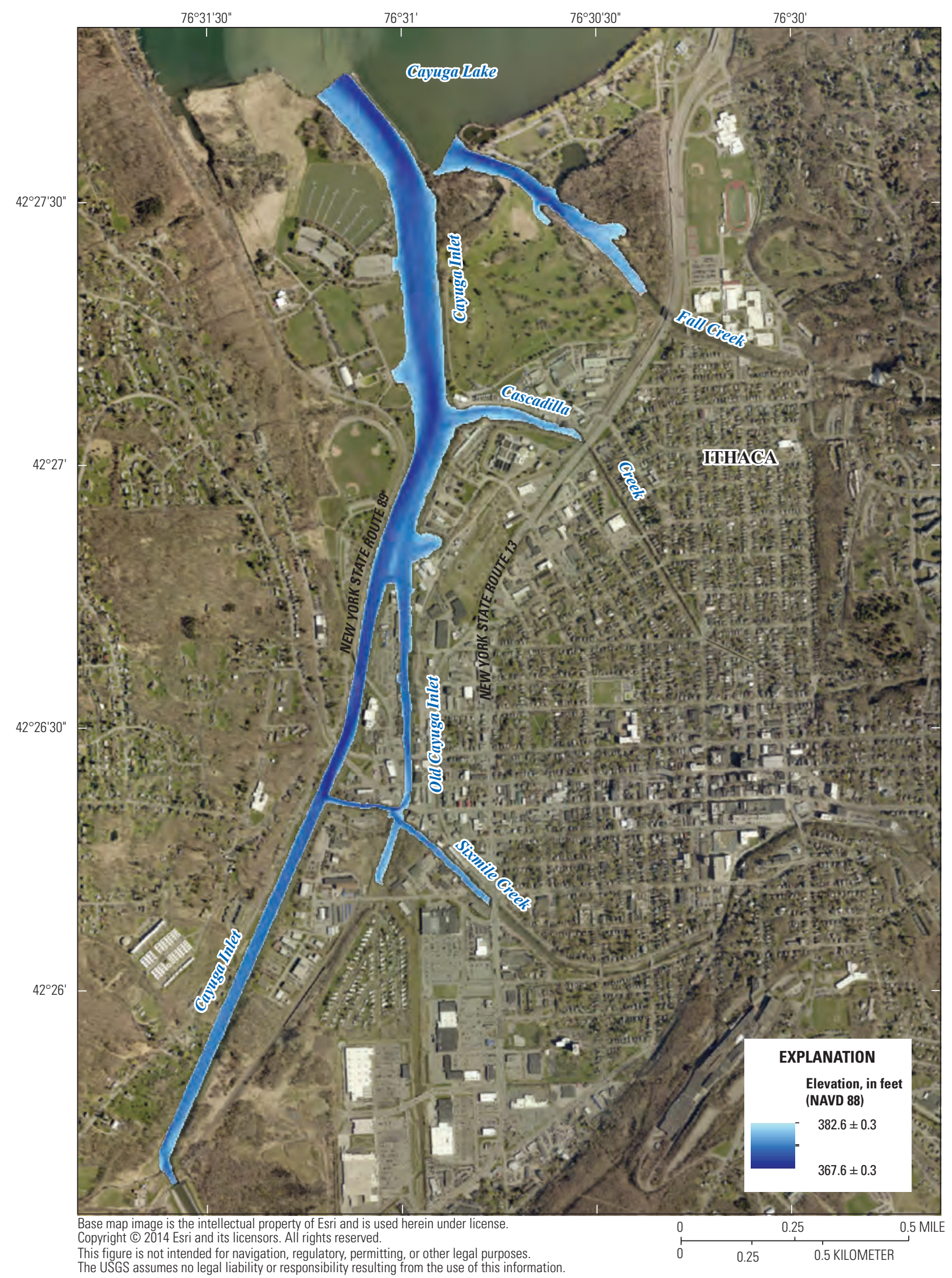

Figure 3. Bathymetric surface of the Cayuga Inlet flood-control channel and selected tributaries, Ithaca, New York. 


\section{Summary}

A bathymetric survey of the Cayuga Inlet flood-control channel, including the Old Cayuga Inlet channel and the mouths of Sixmile Creek, Cascadilla Creek, and Fall Creek in Ithaca, New York, was conducted by the U.S. Geological Survey (USGS), in cooperation with the City of Ithaca, N.Y., and the New York State Department of State, during July 14-20, 2016. The bathymetric data were collected with an acoustic Doppler current profiler along transects spaced about 100 feet apart along the study reach. Horizontal control of the surveyed points was maintained by the use of an onboard real-time kinematic Global Positioning System and an onshore RTK base station. A quality-assurance survey provided a second set of data, which enabled assessment of the accuracy of the measured depths. A USGS streamgage in the study reach provided water-surface elevations from which water depths were subtracted to obtain channel-bottom elevations. Geographic information system software was used to create a bathymetric surface from the bottom elevations. The bathymetric data and surface are available online as a separate data release.

The survey was conducted to meet the modeling needs of a concurrent flood-inundation study by the USGS. The bathymetric data can also be used to inform government agencies charged with maintaining the depth of the flood-control channel to design levels and the navigational capacity of the Cayuga Inlet as part of the New York State Canal System.

\section{Acknowledgments}

The authors would like to recognize Nolan Milliman of the U.S. Geological Survey for his skillful piloting of the survey boat, which permitted accessing and surveying difficultto-reach areas of the study reach.

\section{References Cited}

Esri, 2016, ArcGIS: Esri website, accessed September 17, 2016, at http://www.esri.com/software/arcgis/.

HYPACK, Inc., 2015, HYPACK hydrographic survey software, version 15.0: HYPACK, Inc., website, accessed November 2015 at http://www.hypack.com.
National Geodetic Survey, 2015, OPUS - Online Positioning User Service: National Geodetic Survey database, accessed November 2015 at http://www.ngs.noaa.gov/OPUS/.

National Geodetic Survey, 2016, VERTCON—North American vertical datum conversion: National Geodetic Survey, accessed September 17, 2016, at http://www.ngs.noaa.gov/ TOOLS/Vertcon/vertcon.html.

New York State Department of Environmental Conservation, 2016, Ithaca flood damage reduction project: New York State Department of Environmental Conservation, accessed on September 7, 2016, at http://www.dec.ny.gov/docs/ water_pdf/fcpprjithaca.pdf.

SonTek, 2015a, RiverSurveyor S5 and M9: SonTek web page, accessed June 20, 2016, at http://www.sontek.com/ productsdetail.php?RiverSurveyor-S5-M9-14.

SonTek, 2015b, RiverSurveyor LIVE (RSL): SonTek web page, accessed June 20, 2016, at http://www.sontek.com/ softwaredetail.php?RiverSurveyor-LIVE-RSL-34.

U.S. Army Corps of Engineers, 2002, Engineering and design-Hydrographic surveying manual: U.S. Army Corps of Engineers EM 1110-2-1003, 510 p.

U.S. Army Corps of Engineers, 2011, Hydraulic analysis and impacts of long term shoaling for Flood Risk Management Project, Cayuga Inlet, Ithaca, New York: U.S. Army Corps of Engineers, Buffalo District, 13 p. plus appendices.

U.S. Geological Survey, 2016, USGS 04233500 Cayuga Inlet (Cayuga Lake) at Ithaca, NY: U.S. Geological Survey National Water Information System database, accessed September 17, 2016, at https://waterdata.usgs.gov/ny/nwis/ inventory $/$ ?site_no $=04233500 \&$ agency_cd $=$ USGS.

Wernly, J.F., and Nystrom, E.A., 2016, Geospatial dataset of bathymetric survey of the Cayuga Inlet flood-control channel and selected tributaries, Ithaca, New York, 2016: U.S. Geological Survey data release, accessed December 15, 2016, at https://dx.doi.org/10.5066/F7K935NQ.

Wilson, G.L., and Richards, J.M., 2006, Procedural documentation and accuracy assessment of bathymetric maps and area/capacity tables for small reservoirs: U.S. Geological Survey Scientific Investigations Report 2006-5208, 24 p. 

For more information about this report, contact: Director, New York Water Science Center U.S. Geological Survey

30 Brown Road

Ithaca, NY 14850

dc_ny@usgs.gov

(518) 285-5602

or visit our website at

https://ny.water.usgs.gov

Publishing support provided by the Pembroke and Rolla Publishing Service Centers 


\section{$\frac{\mathbb{2}}{\mathscr{3}}$}

